\title{
PENGEMBANGAN MEDIA PUZZLE GAME MATERI GAYA UNTUK KELAS IV SEKOLAH DASAR
}

\author{
Rindi Arti Defi, Zainul Abidin, Susilaningsih \\ Teknologi Pendidikan Fakultas Ilmu Pendidikan Universitas Negeri Malang \\ Jalan Semarang No. 5 Malang 65145-0341-5747001 \\ rindiartidefi@gmail.com
}

Article History

Received: 05 November 2020, Accepted:12 Maret 2021, Published: 20 November 2021

\begin{abstract}
Abstrak
Peningkatan pemahaman siswa dapat dilakukan dengan menggunakan media game sugam pada saat proses pembelajaran. Pengembangan ini bertujuan menghasilkan suatu produk media game sugam (susun gambar) materi Gaya yang layak dan menarik digunakan untuk memudahkan dalam proses penyampaian materi pada saat pembelajaran. Pada game ini terdapat tantangan yang dapat memotivasi dalam diri siswa. Media ini berbentuk puzzle game sugam (susun gambar). Pengembangan ini menggunakan model pengembangan menurut Lee \& Owens. Tanggapan diperoleh dari ahli media dan ahli materi setelah uji coba produk. Uji coba pemanfaatan produk dilakukan oleh seluruh siswa kelas IV. Secara keseluruhan produk media game sugam (susun gambar) layak untuk digunakan dalam pembelajaran
\end{abstract}

Keyword: game; puzzle; Pemahaman,

\begin{abstract}
Increasing students' understanding can be done by using media game sugam during the learning process. This development aims to produce a media product game sugam(stacking pictures) of material styles that are feasible and attractive to use to facilitate the process of delivering material at the time of learning. In this game, there are challenges that can motivate students. This media is in the form of a puzzle game Sugam(stacking pictures). This development uses a development model according to Lee \& Owens. Responses were obtained from media experts and material experts after product trials. The product utilization trial was conducted by all fourth grade students. Overall Media product game sugam (Arrange pictures) suitable for use in learning.
\end{abstract}

Keyword: game; puzzle; understanding, 


\section{PENDAHULUAN}

Pendidikan merupakan suatu peranan yang sangat penting dalam kehidupan suatu bangsa. Pada saat ini pendidikan sudah mengalami perubahan yang sangat pesat, dimana perubahan ini ditandai dengan perkembangan IPTEK (Ilmu Pengetahuan dan Teknologi) yaitu menggunakan media pembelajaran berbasis teknologi. Dengan memfasilitasi sebuah inovasi dalam pembelajaran yaitu dengan memanfaatkan IPTEK untuk dapat menciptakan sebuah media pembelajaran yang mampu memberikan kenyamanan kepada penggunanya. Salah satu cara penggunaan teknologi yang baik yaitu dengan memanfaatkan sumber teknologi sebagai media dalam proses pembelajaran (Akhmadan, 2017). Guru dapat menggunakan serta memanfaatkan berbagai media berbasis kemputer sesuai dengan kebutuhan dan tujuan pembelajaran. Penelitian yang dilakukan oleh (Husna, 2017). Dalam pembelajaran, perkembangan teknologi saat ini berpengaruh kepada lingkup pendidikan sekolah dasar (SD) terhadap pemilihan materi serta penyampaian materi. Pada jenjang ini, siswa (peserta didik) lebih tertarik dengan sebuah permainan atau game. Menurut Piaget, usia anak sekolah dasar dengan rentang usia 7 tahun hingga 12 tahun merupakan usia yang memasuki tahap operasional konkret.

Karakteristik game edukasi sebagai media pembelajaran, yaitu: sebagai fantasi, aturan \& tujuan, sensory stimuli, tantangan, misteri, dan kontrol (2009). Menurut Malone dan Lepper (1987) karakterisitk game edukasi yaitu: tantangan, rasa ingin tahu, kontrol, dan fantasi. Karakteristik anak usia sekolah dasar pada tahap ini senang bermain, maka pada pembelajaran dibuat dengan semenarik mungkin yaitu dengan memilih media yang sebelumnya belum pernah digunakan dalam pembelajaran seperti media puzzle. Maka dalam hal ini diperkuat oleh pendapat Ghavami (2016) yaitu dengan penggunaan model pembelajaran kooperatif dengan menggunakan media salah satunya dengan berbasis puzzle. Puzzle merupakan game yang dimana pengguna menyusun pola gambar yang diacak untuk menjadi gambar yang utuh (Firdaus \& Nugroho, 2016). Dengan penggunaan media puzzle game sugam (susun gambar) yang dapat memecahkan masalah pada anak serta melatih ketelitian dan kesabaran dalam menyusun kepingan puzzle.

Berdasarkan hasil observasi di SD Islam Al-Huda menemukan hambatan-hambatan dalam kegiatan belajar pada Mata Pelajaran IPA kelas IV. Permasalahan yang dihadapi anak yaitu sebagian siswa ada yang menerima dengan permainan ada yang tidak menerima dengan permainan, sebagian siswa juga ada yang menerima langsung penugasan adapun yang tidak menerima penugasan. Sebagian siswa kurang tertarik mempelajari materi dan tidak memperhatikan guru pada saat pembelajaran berlangsung. Sebagian siswa juga tidak aktif dalam pembelajaran. Tidak terjadi umpan balik antara guru dan siswa sehingga siswa mengalami kesulitan dalam memahami materi. Pada pembelajaran IPA kelas IV tema 8 "Daerah Tempat Tinggalku" subtema 1 "Lingkungan tempat tinggalku" memuat pembelajaran IPA (Gaya) serta pemanfaatannya dalam kehidupan sehari-hari. Penyampaian materi dilakukan secara serentak (bersamaan) yang membahas berbagai macam gaya. Buku yang menjadi bahan ajar pun hanya memberikan sedikit materi, sehingga dalam penguasaan materi pun kurang memahami isi dari materi.

Tujuan dari pengembangan ini yaitu menghasilkan media pembelajaran berupa game sugam (susun gambar) untuk meningkatkan kemampuan pemahaman materi Gaya pada kelas IV di SD Islam Al-Huda untuk pembelajaran IPA yang layak dan menarik digunakan untuk pembelajaran pada siswa. Dengan demikian media game sugam (susun gambar) bergenre puzzle diharapkan mampu memudahkan dalam proses penyampaian materi pada siswa, menjadikan siswa terlibat langsung dalam pembelajaran menjadikan lebih aktif dan lebih bermakna yang memusatkan konsentrasi siswa sehingga meningkatkan pemahaman materi pada siswa, menarik perhatian siswa meningkatkan minat dan motivasi belajar siswa serta pembelajaran menjadi lebih menyenangkan dengan bermain sambil belajar. 
Berdasarkan permasalahan yang telah disampaikan maka perlu adanya media pembelajaran yang mampu digunakan sebagai penunjang pembelajaran yang inovatif, mampu menarik perhatian siswa serta mampu memotivasi siswa dalam belajar. Yaitu dengan menggunakan media game edukatif seperti puzzle atau susun gambar. Pembelajaran IPA kelas IV Tema 8 "Daerah Tempat Tinggalku" subtema 1 Lingkungan tempat tinggalku memuat materi Gaya perlu menggunakan media yang mampu memotivasi serta meningkatkan minat belajar siswa. Game sugam (susun gambar) merupakan salah satu alternatif media yang dapat memenuhi kebutuhan pada saat pembelajaran

\section{METODE}

Pengembangan media game sugam (susun gambar) menggunakan metode Lee \& Owens (2004). Metode tersebut dipilih karena memiliki urutan langkah yang dalam langkah-langkahnya tersusun secara sistematis dan setiap pada langkahnya memiliki urutan yang tersusun jelas. Metode ini dirasa sangat tepat untuk pengembangan produk media game sugam (susun gambar). Terdapat langkah (tahap) penelitian dan pengembangan metode Lee \& Owens: tahap analisis/assessment yang terdiri dari dua tahap Analisis Kebutuhan dan Analisis Awal Akhir, tahap desain, tahap pengembangan, tahap implementasi, tahap evaluasi. Namun penelitian ini hanya sampai pada tahap development.

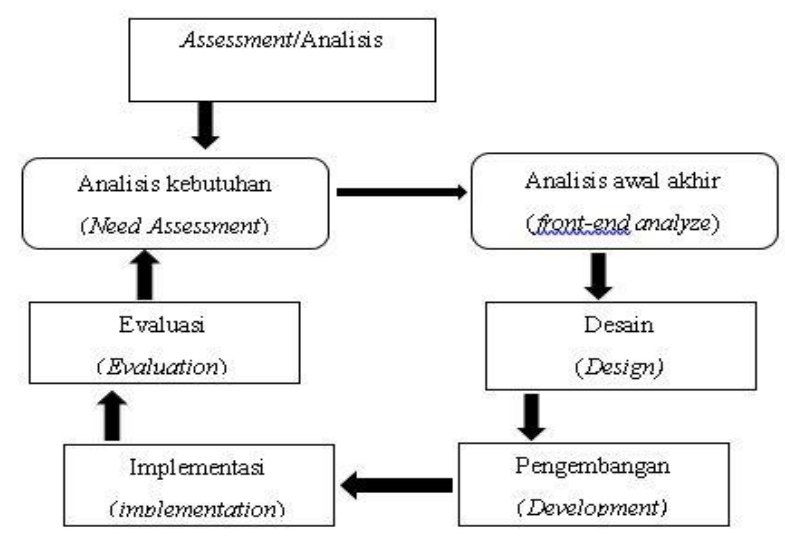

Gambar 1. Model Pengembangan Lee \& Owens (2004)

Tahap analisis (assessment) terdiri dari analisis kebutuhan yang dilakukan dengan wawancara langsung dan observasi yang dilakukan untuk mengetahui kondisi (keadaan) sekolah. Media game sugam (susun gambar) ini dirasa perlu untuk digunakan sebagai penunjang pembelajaran dalam proses pembelajaran materi Gaya. Menjadikan proses pembelajaran lebih menarik, memusatkan perhatian siswa, serta mampu menumbuhkan motivasi belajar dalam diri siswa. Sedangkan analisis awal akhir bertujuan untuk mendapatkan informasi secara detail dan lengkap untuk media yang dikembangkan.

Tahap front-end analyze terdiri dari analisis siswa, analisis teknologi, analisis situasi, analisis tugas, analisis kejadian penting, analisis isu, analisis tujuan, analisis media, dan analisis data. Tujan dari front-end analyze yaitu mendapatkan suatu sumber informasi secara lebih detail untuk mengembangkan produk media yang dikembangkan. Tahap ini menganalisis karakteristik siswa, fasilitas sekolah hingga keadaan di SD Islam Al-Huda agar mendapatkan gambaran informasi secara detail untuk pengembangan yang dilakukan. Sehingga dapat mempermudah dalam menentukan tujuan pembelajaran dan dapat mengantisipasi kesulitan dalam pembelajaran.

Pengembangan media game sugam (susun gambar) dibuat untuk memberkan inovasi baru yang dalam penerapan teknologi pada saat pembelajaran, karena di rasa dapat memotivasi siswa dalam mempelajari suatu materi. Hasil penelitian sebelumnya Putra et al., (2019) menunjukkan bahwa game edukasi menarik bagi pebelajar yang sesuai dengan tujuan pembelajaran sehingga dapat memotivasi siswa dan siswa tidak merasa bosan. Di SD Islam Al-Huda pada tahap uji coba produk dilakukan 
dalam kelas. Karena keterbaatasan fasilitas komputer atau laptop maka, membagi dari beberapa sesi, pada setiap sesi siswa dibagi beberapa kelompok untuk mencoba produk secara berkelompok.

Tahap desain (design), merupakan tahap pengerjaan media yang akan dibuat, seperti merancang spesifikasi media yang akan dikembangkan, merancang desain interface dan komponen lain yang perlu dirancang seperti gambar, potongan-potongan gambar, dan lain-lain. Terdapat desain tampilan pengantar game sugam (susun gambar). Juga terdapat petunjuk penggunaan untuk memainkan permainan.

Pada pengembangan media game sugam (susun gambar) materi gaya menggunakan software utama dalam pembuatannya adalah Articulate Storyline 3 dan perangkat pendukung lainnya. Sebelum diujicobakan kesiswa media ini akan divalidasikan terlebih dahulu ke ahli media dan ahli materi untuk melihat kelayakan media game sugam (susun gambar) yang dikembangkan sebagai media pembelajaran. Kisi-kisi instrumen validasi ahli media berjumlah 41 item pernyataan.Sedangkan kisikisi instrumen ahli materi berjumlah 17 item pernyataan.selanjutnya teknik pengumpulan data yaitu denganmenyebarkan angket responden, soal pre-test dan post-test masing-masing 20 butir soal. Kemudian disebarkan ke siswa kelas IV SD Islam Al-Huda yang terdiri dari 18 siswa.

\section{HASIL}

Media game sugam (susun gambar) termasuk dalam macam puzzle konstruksi. Puzzle rakitan (construction puzzle). Puzzle rakitan (susun gambar) ialah suatu kumpulan potongan-potongan yang terpisah, yang dapat digabungkan kembali menjadi beberapa model. Desain sistem pemilihan menu terdiri dari: tampilan utama yang digunakan untuk memulai permainan, selanjutnya menu pengantar tentang game sugam, kemudian ada dua menu yaitu tampilan menu utama dan icon keluar. Pada tampilan menu utama terdapat empat menu yaitu menu petunjuk penggunaan, menu indikator, menu game, dan data pengembang. Pada menu game terdapat tampilan memasukkan nama untuk memulai suatu game. Kemudahan terdapat beberapa tingkatan dalam game sugam yaitu tingkatan mudah, sedang, dan sulit. Yang kedua terdapat icon keluar pada pojok sisi kanan atas menu tampilan menu utama, yang digunakan untuk keluar dari aplikasi atau kembali ke menu tampilan utama.

Tabel 1. Tanggapan Ahli Media

\begin{tabular}{llcccc}
\hline \multirow{2}{*}{ No } & \multicolumn{1}{c}{ Aspek } & Jumlah Butir & Sangat Setuju & Setuju & Rata-rata \\
\hline $\mathbf{1}$ & Kualitas Teknis & 9 & 7 & 2 & 3,7 \\
\hline $\mathbf{2}$ & Penggunaan Interaksi & 6 & 2 & 4 & 3,3 \\
\hline $\mathbf{3}$ & Kemudahan Pengoperasian & 3 & 0 & 3 & 3 \\
\hline $\mathbf{4}$ & Pemanfaatan & 23 & 19 & 4 & 3,7 \\
\hline
\end{tabular}

Dari tabel yang diperoleh dari tanggpan terhadap ahli media, ahli materi dan ujicoba siswa sebagai pengguna dilakukan bertujuan untuk mengetahui kevalidan media game sugam (susun gambar). Berdasarkan tabel 1 hasil tanggapan ahli media, dari apek Kualitas Teknis memperoleh ratarata sebesar 3,7. Kemudian dari aspek Penggunaan Interaksi memperoleh rata-rata sebesar 3,3. Pada aspek Kemudahan Pengoperasian memperoleh rata-rata 3. Dan aspek Pemanfaatan memperoleh ratarata 3,7. Maka dari hasil ujicoba ahli media dinyatakan layak digunakan sebagai media pembelajaran.

Berdasarkan tabel 2 hasil tanggapan ahli materi, dari aspek Relevansi memperoleh rata-rata sebesar 3,7. Kemudian aspek Keakuratan memperoleh rata-rata 4. Aspek Kelengkapan Sajian memperoleh rata-rata 4. Aspek Konsep Dasar Materi memperoleh rata-rata 4. Aspek Kesesuaian sajian dengan tuntutan pembelajaran yang terpusat pada siswa memperoleh rata-rata 4. Aspek pendukung materi pembelajaran memperoleh rata-rata 3,5. Perolehan tersebut memberikan landasan bahwa secara materi yang disampaikan pada media valid untuk digunakan pembelajaran berdasarkan aspek-aspek tanggapan ahli materi. 
Tabel 2. Tanggapan Ahli Materi

\begin{tabular}{|c|c|c|c|c|}
\hline Aspek & Jumlah Butir & Sangat Setuju & Setuju & Rata-rata \\
\hline Relevansi & 7 & 5 & 2 & 3,7 \\
\hline Keakuratan & 3 & 3 & 0 & 4 \\
\hline Kelengkapan Sajian & 1 & 1 & 0 & 4 \\
\hline Konsep Dasar Materi & 1 & 1 & 0 & 4 \\
\hline $\begin{array}{l}\text { Kesesuaian sajian dengan tuntutan } \\
\text { pembelajaran yang terpusat pada siswa }\end{array}$ & 3 & 3 & 0 & 4 \\
\hline Pendukung materi pembelajaran & 2 & 1 & 1 & 3,5 \\
\hline
\end{tabular}

Dari tabel 3 menunjukkan jumlah 18 audiens (siswa) dengan jumlah pernyataan 10 item meliputi 5 butir pernyataan pada aspek media, 3 aspek pernyataan Materi, dan 2 aspek pernyataan Pembelajaran. Pada butir pernyataan butir 1 kategori sangat setuju berjumlah 18 siswa. Pada butir 2 kategori sangat setuju berjumlah 14 siswa dan kategori setuju berjumlah 4 siswa. Butir pernyataan 3 kategori sangat setuju berjumlah 15 dan kategori setuju berjumlah 5 siswa. Butir pernyataan 4 kategori sangat setuju berjumlah 14 dan kategori setuju berjumlah 4 siswa. Butir pernyataan 5 kategori sangat setuju berjumlah 14 siswa dan kategori setuju berjumlah 4 siswa. Butir pernyataan 6 kategori sangat setuju berjumlah 15 siswa dan kategori setuju berjumlah 3 siswa. Butir pernyataan 7 kategori sangat setuju berjumlah 15 siswa dan kategori setuju berjumlah 3 siswa.. Butir pernyataan 8 kategori sangat setuju berjumlah 18 siswa. Butir pernyataan 9 kategori sangat setuju berjumlah 15 siswa dan kategori setuju berjumlah 3 siswa. Butir pernyataan 10 kategori sangat setuju berjumlah 18 siswa.

Tabel. 3 Tanggapan Siswa (audiens)

\begin{tabular}{cccc}
\hline \multirow{2}{*}{ Aspek } & No. Butir Pernyataan & Sangat Setuju & Setuju \\
\hline \multirow{2}{*}{ Media } & 1 & 18 & 0 \\
\cline { 2 - 4 } & 2 & 14 & 4 \\
\cline { 2 - 4 } & 3 & 15 & 3 \\
\cline { 2 - 4 } & 4 & 14 & 4 \\
\hline Materi & 5 & 14 & 4 \\
\cline { 2 - 4 } & 6 & 15 & 3 \\
\hline Pembelajaran & 7 & 15 & 0 \\
\cline { 2 - 4 } & 8 & 18 & 0 \\
\hline
\end{tabular}

Dari data hasil belajar melalui kegiatan pretest dan posttest yang dilakukan pada 18 siswa terdapat peningkatan rata-rata nilai dari 72,77 menjadi 92,22 . Siswa yang mengalami kenaikan sebanyak 15 siswa dari 18 siswa lainnya dari jumlah total 18 siswa sedangkan 3 siswa lainnya dari jumlah total 18 siswa dinyatakan belum meningkat.

\section{PEMBAHASAN}

Media pembelajaran merupakan bentuk pelaksanaan kemajuan teknologi dan komunikasi yang khususnya di bidang pendidikan. Media yang bertujuan dapat tercapai dengan optimal yang dikemas secara inovatif, menarik, dan menyenangkan (Almeida \& Simoes, 2019; Bayram, 2019). Salah satunya dengan media pembelajaran game edukasi. Dengan menggunakan game edukasi pembelajaran lebih berfokus kepada siswa dan siswa pun memperoleh pembelajaran secara langsung dan mendapatkan pengalaman belajar sambil bermain (Samuel, 2010).

Hasil penelitian ini yaitu media game sugam (susun gambar) dapat meningkatkan pemahaman siswa pada materi gaya. Karena terdapat tantangan serta merasa termotivasi untuk menyelesaikannya. Sejalan dengan penelitian sebelumnya (Yang, 2012), menyebutkan bahwa game edukasi ini harus memiliki tantangan bagi si penggunanya sehingga si pengguna merasa termotivasi dan mahir dalam 
menyelesaikan masalah yang terdapat didalam game. Sejalan juga dengan penelitian sebelumnya (Costa et al., 2018; Pornel, 2014), game edukasi dapat meningkatkan motivasi dalam diri peserta didik. Penggunaan puzzle game sugam (susun gambar) sebagai media pembelajaran mampu mempermudah guru dalam menyampaikan pesan kepada siswa agar mereka aktif, antusias dan lebih termotivasi dalam kegiatan belajar serta menciptakan pembelajaran yang bermakna. Hal ini sejalan dengan penelitian sebelumnya ( $\mathrm{Su}$ et al, 2013) yang menunjukkan bahwa berbagai game mampu menantang dan menarik yang menyebabkan rasa keingintahuan dan didik dalam aktivitas belajar.

Hasil ujicoba yang dilakukan oleh ahli media untuk data kuantitatif, dari 41 item pernyataan berkaitan dengan media ini terdapat 31 item pernyataan yang menjawab alternatif penilaian Sangat Setuju dengan bobot nilai 4 dan alternatif penilaian Setuju dengan bobot nilai 3. Aspek Kualitas Teknis terdapat penilaian (Sangat Setuju) dan (Setuju). Dari 9 butir terdapat 7 butir yang menjawab alternatif penilaian Sangat Setuju dan 2 butir menjawab alternatif penilaian Setuju. Kemudian pada aspek Penggunaan Interaksi juga terdapat penilaian alternatif (Sangat Setuju) dan (Setuju). Dari 6 item pernyataan terdapat 2 item pernyataan menjawab alternatif penilaian Sangat Setuju dan 4 item pernyataan lainnya menjawab alternatif Setuju. Pada aspek Kemudahan Pengoperasian terdapat alternatif penilaian (Sangat Setuju). Dari 3 item pernyataan menjawab alternatif Setuju. Pada aspek Pemanfaatan terdapat penilaian (Sangat Setuju) dan (Setuju). Dari 23 item pernyataan, dari 19 item pernyataan menjawab alternatif penilain (Sangat Setuju) dan 4 item lainnya menjawab pernyataan dengan alternatif Setuju. Selain itu ahli media juga memberikan komentar dan saran. Ahli media berkomentar yaitu secara umum kualitas produk sudah cukup baik, ada beberapa aspek yang perlu dioptimalkan, bukan pada kualitas teknis dan desain visual, tetapi pada relevansi dan proyeksi efektivitas performannya berdasarkan KD atau tujuan pembelajaran.

Hasil ujicoba ahli materi untuk data kuantitatif, dari 17 item pertanyaan yang berkaitan dengan materi terdapat 14 item pernyataan yang menjawab alternatif penilaian Sangat Setuju dengan bobot nilai 4 dan alternatif penilaian Setuju dengan bobot nilai 3.Dari aspek Relevansi terdapat penilaian dengan alternatif Sangat Setuju dan Setuju. Dari 7 item pernyataan, terdapat 5 item pernyataan menjawab alternatif Sangat Setuju dan 2 item pernyataan menjawab alternatif penilaian Setuju. Pada aspek Keakuratan menjawab alternatif penilaian Sangat Setuju terdapat 3 item pernyataan. Pada aspek Kelengkapan Sajian menjawab alternatif penilain Sangat Setuju terdapat 1 item pernyataan. Pada aspek Konsep Dasar Materi menjawab alternatif penilaian Sangat Setuju juga terdapat 1 item pernyataan. Pada aspek Kesesuain sajian dengan tuntutan pembelajaran yang terpusat pada siswa menjawab alternatif penilaian Sangat Setuju terdapat 3 item pernyataan. Pada aspek Pendukung materi pembelajaran terdapat penilaian dengan alternatif Sangat Setuju dan Setuju. Dari 2 item pernyataan, 1 item pernyataan menjawab pernyataan dengan alternatif Sangat Setuju dan 1 item menjawab pernyataan dengan alternatif Setuju. Ahli materi juga memberikan komentar dan saran. Ahli materi berkomentar yaitu dalam meningkatkan kemampuan pemahaman siswa pada pelajaran tema 8 tentang gaya dengan media game sugam (susun gambar) sudah sangat efektif, karena siswa dapat berfikir aktif selama pembelajaran berlangsung dan materi dalam media sudah sesua dengan yang dibelajarkan.

Kemudian dilakukan uji coba kepada 18 siswa/audiens (sebagai pengguna), sebanyak 7 siswa yang menjawab alternatif (Sangat Setuju) dalam 10 item pertanyaan dengan bobot 4. Meliputi aspek media, materi, dan pembelajaran. Sedangkan 11 siswa menjawab 3 item pertanyaan dengan alternatif (Sangat Setuju), meliputi item pertanyaan: saya tertarik dengan menggunakan media game sugam (susun gambar), materi ini sangat bermanfaat untuk saya dalam kehidupan sehari-hari, dan penggunaan media game sugam (susun gambar) efektif bagi saya dalam pembelajaran. Sedangkan 7 item pertanyaan menjawab alternatif (Setuju) meliputi item pertanyaan: saya mudah menggunakan media game sugam (susun gambar), saya tertarik dengan tampilan media game sugam (susun gambar), media game sugam (susun gambar) ini sangat efektif bagi saya untuk menunjang pembelajaran saya, 
saya mudah untuk memaham petunjuk penggunaan, materi gaya ini mudah untuk saya pelajari, saya mudah untuk memahami materi dengan menggunakan media game sugam (susun gambar), dan media game sugam (susun gambar) meningkatkan minat belajar saya. Siswa juga memberikan tangggapan yaitu dari tanggapan dapat disimpulkan siswa sangat senang dan merasa tertarik menggunakan media game sugam (susun gambar). Berdasarkan kriteria kelayakan aspek penilaian yang termasuk dalam kualifikasi layak.

Menurut (Alessi \& Trollip, 2001), game edukasi memiliki komponen hiburan yang dapat membantu siswa untuk mempelajari materi dengan lebih menyenangkan, terlepas dari suka atau tidak sukanya siswa terhadap materi pelajaran tersebut. Menurut (Aykac \& Kogce, 2019) game edukasi dapat meningkatkan kompetensi guru pra-jabatan dalam perencanaan dan penerapan penggunaan game dalam instruksi pencapaian kursus sekolah dasar dan pada siswa dalam memahami pembelajaran pun meningkat setelah menggunakan game edukasi.

Penelitian sebelumnya juga menyatakan bahwa game edukasi kaloboratif tidak hanya untuk meningkatkan aktivitas belajar dan motivasi belajar saja, namun juga untuk meningkatkan prestasi belajar pada siswa. Hal ini juga dijelaskan dari penelitian sebelumnya yaitu media game edukasi memiiki beberapa kelebihana dari pada media konvensional, kelebihan utama dari game edukasi yaitu visualisasi dari permasalahan yang nyata (Vitianingsih, 2016). Dari yang telah dijelaskan sebelumnya (Shu \& Liu, 2019), belajar melalui permainan tujuannya agar siswa tidak merasa bosan atau jenuh pada saat pembelajaran dan menumbuhkan semangat dalam belajar. Berdasarkan penelitian sebelumnya (Saksrisathaporn \& Sribunthankul, 2019), game pembelajaran berbasis smartphone terbukti efektif sebagai media pembelajaran yang menunjukkan manfaat sistem pembelajaran berbasis permainan pada pembelajaran mandiri dalam kimia. Demikian pula penelitian yang telah dilakukan oleh Setyawan et al., (2019) menunjukkan bahwa game edukasi daapatmendorong siswa untuk bermain lebih lama, sehingga dapat mempertahankan fokus belajarnya.

Bermain "Puzzle adalah permaian yang terdiri atas kepingan-kepingan dari satu gambar tertentu yang dapat melatih tingkat konsentrasi” (Soebachman, 2012). Berdasarkan penelitian sebelumnya (Jin, Nakayama \& Tu, 2020), menyatakan bahwa metode pembelajaran berbasis game dapat meningkatkan belajar pada siswa. Pembelajaran berbasis permainan muncul dan berkembang pesat dengan bantuan komputer. Penelitian sebelumnya juga menjelaskan bahwa game edukasi komputer yang dipersonalisasi tidak hanya mampu mendorong siswa untuk belajar saja, namun juga mampu untuk meningkatkan hasil belajar siswa (Hwang et al., 2012; Kinzie \& Joseph, 2008). Media puzzle game sugam (susun gambar) mempunyai manfaat yaitu dapat digunakan sebagai stimulus perkembangan anak terutama dalam perkembangan kognitifnya. Hal ini dijelaskan menurut (Adenan, 1989) bahwa "Puzzle dan games adalah materi untuk memotivasi diri secara nyata dan merupakan daya penarik yang kuat. Puzzle dan games untuk memotivasi diri karena hal itu menawarkan sebuah tantangan yang dapat secara umum dilaksanakan dengan berhasil".

Pembelajaran dengan berbasis game mampu menjadikan solusi atau alternatif yang mampu meningkatkan motivasi belajar siswa (Sukirman, 2017). Seperti yang telah dipaparkan pada penelitian sebelumnya Prasetiawan et al., (2019) media game sangat efektif dan menarik minat belajar pada siswa dalam penggunaanya. Penggunaan game puzzle dapat meningkatkan kemampuan berpikir siswa. Siswa mampu mengembangkan pola pikirnya dengan bermain game puzzle. Hal ini telah dibuktikan Aini et al., (2019) media game puzzle berpengaruh kepada kemampuan berpikir siswa yang bertujuan untuk meningkatkan kemampuan berpikir melalui minat belajar. Namun, akan lebih baik jika game yang dikembangkan memiliki kemampuan menyesuaikan diri dengan karakteristik pengguna dan memberikan rekomendasi sesuai progess belajar siswa (Surahman \& Surjono, 2017, Surahman \& Alfindasari, 2018). 
Hasil penelitian sebelumnya telah dibuktikan Herawati et al., (2013) siswa menggunakan puzzle mampu memahami konsep serta mampu menyelesaikan sebuah permasalahan dengan saling menghargai pendapat teman sesama anggota kelompok. Hasil penelitian dari Nuranisa et al., (2018) bermain puzzle yang dilakukan secara bersamaan dapat membantu anak dalam mengembangkan kemampuan bersosialisasi melauli kerjasmaa satu sama lain dan usaha dan usaha anak untuk menyelesaikan tugas permainan puzzle sendiri akan membantu kemandirian anak dalam menyelesaikan masalah. Berdasarkan hasil penelitian terdahulu yang telah dibuktikan, media game bermedia Flash puzzle dalam penerapannya pada kegiatan kelas dinyatakan layak digunakan dalam pembelajaran (Widyatmoko ET 1., 2019).

Penelitian yang dilakukan oleh (Fitriyani \& Anafiah, 2017), menunjukkan keterampilan menulis paragraf melalui media puzzle mengalami peningkatan. Maka dengan adanya media puzzle siswa merasa terhibur yang membuat suasana dalam kelas lebih menyenangkan (Faridha, 2015). Penelitian sebelumnya menunjukkan hasil uji coba di SD Banjaran 6, dengan media puzzle memenuhi kriteria (Rumakhit, 2017). Penelitian yang dilakukan Hardiyanti et al. (2020) menghasilkan produk Game puzzle Berbasis Construct 2 Sebagai Media Pembelajaran Sistem Peredaran Darah Kelas XI di SMA Negeri 1 Selayar. Berdasarkan dari hasil uji coba kelayakan oleh ahli media dan ahli materi produk dinyatakan layak digunakan dalam proses pembelajaran.

\section{SIMPULAN}

Media pembelajaran game sugam (susun gambar) pembelajaran IPA kelas IV Tema 8 "Daerah Tempat Tinggalku" subtema 1 Lingkungan tempat tinggalku memuat materi Gaya dinyatakan memenuhi kritria valid. Artinya, media game sugam (susun gambar) ini layak digunakan sebagai media penunjang pembelajaran tambahan serta efektif mampu meningkatkan pemahaman siswa. Media ini dapat dijadikan solusi dalam permasalahan pembelajaran dan mampu digunakan sebagai penunjang pembelajaran yang inovatif, mampu menarik perhatian siswa serta mampu memotivasi siswa dalam belajar. Berdasarkan tanggapan yang dilakukan kepada ahli media, ahli materi, dan siswa sebagai pengguna seluruhnya memenuhi kriteria layak. Dari hasil dapat ditarik kesimpulan bahwa media game sugam (susun gambar) materi Gaya dinyatakan layak untuk digunakan sebagai media pembelajaran. Hal ini dapat dibuktikan dengan angket ahli media dan ahli materi yang memebrikan jawaban dengan bobot (3) dengan kriteria Baik sampai dengan bobot (4) dengan kriteria Sangat Baik. Siswa sebagai pengguna memberikan tanggapan yang memilih alternatif hawaban dengan bobot (3) dengan kriteria Baik sampai dengan bobot (4) dengan kriteria Sangat Baik.

\section{DAFTAR RUJUKAN}

Adenan, P. (1989). Sejarah Puzzle. Jakarta: Rineka Cipta.

Aini, O. B, Ayu, C. K., \& Siswati. (2019). Pengembangan game puzzle sebagai edgame berbasis andorid untuk meningkatkan kemampuan berpikir matematka siswa SD. Jurnal Teori dan Aplikasi Matematika (JTAM), 3(1) 74-79.

Alessi, S. M., \& Trollip, S. R. (2001). Multimedia for learning: Methods and development. Allyn \& Bacon.

Almeida, F. \& Simoes, J. (2019). The role of serious games, gamification and industry 4.0 tools in the education 4.0 paradigm. Contemporary Educational Technology, 10(2) 120-136.

Aykac, M. \& D. (2019). Preservice Clasroom Teachers' Opinions on Use of Educational Games in Instructions of Primary School Courses. Educational Policy Analysis and Strategic Reserch, 14(1), 116-143.doi: 10.29329/epasr.2019.186.7.

Bayram, S. (2019). World journal on educational technology: Current issues. 11(1), I.

Costa, C., Tyner, K., Henriques, S., \& Sousa, C. (2018). Game creation in youth media and information literacy education. Internasional Journal of Game-Based Learning (IJGBL), 8(2), $1-13$. 
Faridha, Ayu., \& Abbas, N. (2015). Penerapan Think Pair Share berbantuan Puzzle untuk Meningkatkan Kualitas Pembelajaran IPS. Joyful Learning Journal. 4(2) 2252-6366.

Firdaus, M., \& Nugroho, H. W. (2016). Rancangan Bangun Game Edukasi Asah Otak Anak Berbasis Android Menggunakan Aplikasi Contruct 2. Konvergensi, 12(01).

Ghavami, Elham. (2016). Comparison of the ITT and Puzzle-Based Teavhing Methods withRespect to the Lecturing Method in the Educational Progress of the Computer Science Basics Course of High School's $3^{\text {rd }}$ Grade of Math-Physics Students of Urmia's $1^{\text {st }}$ District. International Journal of Humanities and Cultural Studies.

Hardiyanti, S., Mustami, K., M., \& Mu'nisa, A. (2020) Pengembangan Game Puzzle Berbasis Construct 2 Sebagai Media Pembelajaran Sistem Peredaran Darah Kelas XI di SMA Negeri 1 Selayar. Biolearning Journal, 7(1).

Herawati, A. (2013). Pembelajaran kooperatif TAI dan game puzzle dalam meningkatkan motivasi Belajar dan pemahaman konsep. Jurnal Pendidikan Sains, 1(2) 126-1132.

Husna, N. (2017). Pengembangan Media Puzzle Materi Pencemaran Lingkungan di SMP Negeri 4 Banda Aceh. Jurnal Pendidikan Sains Indonesia. 5(1): 66-71.

Jin, G., Nakayama, S., \& Tu, M. (2020). Game Based Learning for Safety and Security Education. Journal of Education and Learning (EduLearn), 14(1) 114-122.

Lee, W. W., \& Owens, D. L. (2004). Multimedia-based instructional design: computer-based training, web-based training, distance broadcast training, performance-based solutions. John Wiley \& Sons.

Malone, T. W., \& Lepper, M. R. (1987). Making Learning Fun: A Taxonomy of Intrinsic Motivations for Learning. Aptitude, Learning, and Instruction. Volume 3: Conative and Affective Process Analyses.

Nuranisa, L. (2018). Puzzle Sebagai Media Bermain untuk Melatih Kemandirian Anak Usia Dini, Jurnal Pendidikan Early Childhood, 2(2).

Samuel, H. (2010). Cerdas Dengan Game: Paduan Praktis Bagi Orang Tua Dalam Mendampingi Anak Bermain Game. Jakarta: Gramedia Pustaka Utama.

Saksrisathaporn, K., \& Sribunthankul, P. (2019). A Smartphone Game to Promote Self-Learning in Chemistry. 16 th Internasional Conference on Cognition and Exploratory Learning in Digital Age (CELDA 2019).

Setyawan, W. C., Sulthoni, S., \& Ulfa, S. (2019). Pengembangan Multimedia Game Edukasi Ipa Lapisan Bumi Untuk MTS. Jurnsl Kajian Teknologi Pendidikan, 2(1), 30-36.

Shu, L., \& Liu, M. (2019). Student engagement in game-learning A literature review from 2008 to 2018. Journal of Educational Multimedia and Hypermedia, 28(2), 193-215.

Soebachman, A. (2012). Permainan Asyik Bikin Anak Pintar. Yogyakarta: In Azna Books.

Sukirman. (2017). Peningkatan atmosfer belajar siswa generasi digital native melalui pembelajaran Berbasis game. Portal Publikasi Ilmiah UMS.

Surahman, E., \& Surjono, H. D. (2017). Pengembangan adaptive mobile learning pada mata pelajaran biologi SMA sebagai upaya mendukung proses blended learning. Jurnal Inovasi Teknologi Pendidikan, 4(1), 26-37.

Surahman, E., \& Alfindasari, D. (2017, September). Developing adaptive mobile learning with the principle of coherence Mayer on biology subjects of high school to support the open and distance education. In 3rd International Conference on Education and Training (ICET 2017) (pp. 184-190). Atlantis Press.

Vitianingsih, A. V. (2016). Game Edukasi Sebagai Media Pembeajaran Pendidikan Anak Usia Dini. Jurnal INFORM, 1(1) 2502-3470. 
Putra, A. P., Soepriyanto, Y., \& Husna, A. (2019). Pengembangan multimedia game edukasi tentang keragaman masakan khas daerah-daerah di Indonesia untuk kelas V SD. Jurnal Kajian Teknologi Pendidikan, 1(4) 299- 306.

Prasetiawan, F., Abidin, Z., \& Adi, P.E., (2019). Multimedia berfitur puzzle untuk materi perjuangan memprolamasikan kemerdekaan Indonesia. Jurnal Kajian Teknologi Pendidikan, 2(2) 882-89.

Widyatmoko, H. (2019) The Development of Educational Puzzle Game Based on The Local Wisdom Using Flash Media to Educate the Syudents' Characteristic of Primary School. Jurnal Ilmiah Kependidikan. 9(2).

Yang, Y.-T.C. (2012). Building virtual cities, inspiring intellegent citizens: Digital games for developing students' problem solving and learning motivation. Computers \& education, 59(2), 365-377. 